\title{
FORMATION OF THE PROFESSIONAL COMPETENCE OF FUTURE PRIMARY TEACHERS WITH THE USE OF MODERN TEACHING METHODS
}

\author{
Nataliia Opanasenko \\ Pereiaslav-Khmelnytskyi Hryhorii Skovoroda State Pedagogical University, Ukraine \\ Halyna Chernenko \\ Pereiaslav-Khmelnytskyi Hryhorii Skovoroda State Pedagogical University, Ukraine
}

\begin{abstract}
The article considers the problem of formation of professional competence of future primary teachers. The regulatory framework governing the professional activities of teachers in Ukraine ("Concept of development of Pedagogical Education", "Professional Standard "Primary School Teacher of Secondary Education") is analyzed. The urgency of the problem of future schoolteachers' professional training for the modern school, which is being studied within the framework of the project "New Ukrainian School - New Teacher" is proved.

The definitions of "competence", "professional competence", "professionalism" of both national and international scientists are analyzed.

It is proved that professional competence is an integrative characteristic of business and personal qualities of a specialist, reflects the level of knowledge, skills and experience required to achieve the goal of a certain type of professional activity, as well as the moral position of a specialist.

The article presents modern methods of training future primary school teachers: "designthinking" as a creative way of thinking, aimed at creating non-standard solutions and innovations for the formation of professional competence of future teachers of primary education (stages of "design- thinking”: empathy, focusing, ideas generation, prototyping, testing); interactive teaching methods ("lotus blossoming”, mixed media, jury, presentations, etc.), focus group research.

The article proves the idea that the formation of key competences of students in the New Ukrainian School, competitiveness and ability to enter the world global space depend on the professional competence of the teacher.
\end{abstract}

Keywords: future teachers of primary education, modern methods of education, professional competences, professional training, the New Ukrainian School.

\section{Introduction}

The current state of the development of the society in Ukraine, which is characterized by accelerated progress of technologies, requires cardinal changes in education. In modern conditions, teacher training should meet public requirements formulated in professional and educational standards, take into 
Opanasenko \& Chernenko, 2020. Formation of the Professional Competence of Future Primary Teachers with the use of Modern Teaching Methods

account global trends and recommendations of influential international organizations for teacher training.

The urgency of this topic can be traced in the approved "Concept for the development of pedagogical education", the aim of which is to improve the system of pedagogical education to create a training base for teachers of the new generation, providing conditions for the creation and development of modern alternative models of uninterrupted professional and personal development of teachers (On approval of the concept, 2018). Therefore, special attention should be paid to the problem of the professional training of future primary school teachers in the New Ukrainian School, which was launched in 2018. This problem in Ukraine is being investigated in the framework of the project "New Ukrainian School - New Teacher".

The purpose of the article is the research of the professional competence formation process in future primary school teachers using modern teaching methods.

The main methods of studying the problem were: testing, method of analysis of pedagogical situations (cases), focus group survey. The method of testing made it possible to test the theoretical knowledge of professional disciplines among future primary school teachers. The analysis of pedagogical situations implied that students would solve pedagogical tasks in which the problem situation was simulated. Their solution enabled the identification of a package of knowledge, skills and competencies needed for future primary school teachers. The focus group survey method helped to identify the range of opinions of future primary school teachers on their level of professional competence and to justify ways of improvement.

The experiment involved third-year students (36 people) of the Pedagogical Faculty, specialty "Primary education".

\section{Theoretical overview of the problem}

It should be noted that recently the problem of teachers' competence has been in the focus of researchers' attention. Competent approach in education has been studied by both national and foreign scientists, in particular, N. Bibik, M. Kubitskaya, I. Onyshchenko, I. Osadchenko, S. Skvortsova, L. Khoruzha and others.

Thus, the ethical competence of a future primary school teacher is quite deeply revealed in the monograph by L. Khoruzha (2003). The problem of forming a teacher's professional competence and its types was studied by S. Skvortsova (2009). M. Kubitskaia opened the questions of the competent approach to a teacher's professional training. She substantiated the concept of "professional competence", defined the competences that the future teacher 
should possess (Kubitskaia, 2016).

But, despite a significant number of scientific publications, in which the problem of professional teacher training was researched, today it requires a new vision, new approaches due to the requirements of the New Ukrainian School.

The research of the problem convinced that the main characteristics of the future modern teacher should be professionalism, competence, public interest in the competence approach, self-organization, creativity. Therefore, the new paradigm of higher education should provide for creation of a new educational space that will provide quality training of future specialists for professional and research activities in the New Ukrainian School.

In our study, the concept of "competence" is defined as "the possession of appropriate knowledge and abilities that enable a person to make a thorough judgment about a certain area and act effectively in it” (Bibik, 2004).

By "professional competence" we understand the integrative characteristic of business and personal qualities of a specialist, reflects the level of knowledge, skills, experience sufficient to achieve the goal in a certain type of professional activity, as well as the moral position of a specialist (Encyclopedia of Education, 2004).

Today, the professional competence of future primary school teachers must correspond to the work functions specified in the professional standard "Primary school teacher of the institution of comprehensive secondary education", approved by the Ministry of Social Policy of Ukraine. These are such labour functions:

- planning and implementation of the educational process;

- $\quad$ ensuring and supporting the learning, upbringing and development of students in an educational environment and family;

- creating an educational environment;

- reflexion and professional self-development;

- conducting educational research;

- providing methodological assistance to colleagues in the education, development and socialization of primary school pupils in the secondary comprehensive school system;

- generalization of own pedagogical experience and its presentation to the pedagogical community;

- assessment of the performance of primary school teachers in the institution of general secondary education (On approval of the professional standard, 2018).

In our opinion, the training of future primary school teachers in pedagogical higher education institutions needs to be updated and improved in order to successfully perform these jobs. 
Opanasenko \& Chernenko, 2020. Formation of the Professional Competence of Future Primary Teachers with the use of Modern Teaching Methods

Studying this problem about the formation of the future primary school teachers' professional competence, we used such modern teaching methods in the process of teaching special subjects as:

1. The method of "design-thinking" is a creative way of thinking, aimed at creating non-standard solutions and innovations (Zubkova, 2019). The main task of this method was to generate new solutions and find creative ways to solve pedagogical problems. It is aimed at forming teamwork skills, developing emotional intelligence, as well as critical and creative thinking of the student. The method consists of certain stages, the application of which in the right sequence leads to the desired result: empathy, focusing, generation of ideas, prototyping, testing (Zubkova, 2019). Thus, using this method of "design- thinking" in the study of the academic subject "didactics" with the 3rd-year students of the Faculty of Pedagogy (36 students), we defined the requirements to the teacher of the New Ukrainian School. In particular, the students were asked the question "What should a teacher of the New Ukrainian School be like? Answering this question, the students gradually went through the stages of "design-thinking". The methodology was implemented through the following rules: dividing students into groups; selecting a speaker in a group; interview questions (10 different questions: open, hypothetical, clarifying, which were related to the speaker of another group); discussion of the survey results; highlighting dominant ideas and preparation of presentations.

As the results of the research have shown, all groups in their presentations noted the dominant professional qualities of the modern teacher: creativeness, imagination, knowledge of professional methods, which are the components of the professional competence of a New Ukrainian School teacher.

2. The method of creative thinking "lotus blossom" - an active method of education, which affects the development of thinking, creativity, initiative of students. It enables future specialists to orientate themselves in the pedagogical profession and understand educational competitiveness in the labor market. The method of "lotus blossom" suggests the observance of certain rules and sequence of actions: record on the center of the main theme; record on a circle the concept on the main theme (there should be several circles). The process continues until the "lotus blossom" chart is finished. In the "lotus blossom" method, some ideas transfer to the others and it seems that they appear independently. For example, the "lotus blossom" method was used in the course of studying the topic "The developing nature of learning in modern school" in the subject "didactics". In this way, students revealed the didactic value of one of the approaches of the developing learning method: "Help the child to do it himself".

3. The mindmaps method is a method that allows to structure and visualize students' knowledge in order to generalize a lot of information and highlight basic concepts (Korotiaieva \& Kandyba, 2019). The scheme of the method: a theme is 
written on the board; a group offers and organizes ideas and information, presenting them visually, often in clusters. For example, one of the topics for study was "A textbook for the New Ukrainian School”. The following issues were discussed by the students: Why should the developing focus of the textbook be strengthened in a person-oriented education environment? What do we mean by "A Textbook for the New Generation"? Why is it particularly important to develop the skills needed for the primary school students to work with the textbook in the conditions of the information society?

4. Mixed media method (using PowerPoint, multimedia whiteboards, video) plays an important role in the professional training process of students (Shevchenko, 2012). The method of the organization of information involves the use of information elements in a mixed sequence. Students work in pairs or in small groups to organize them. It is appropriate to use multimedia presentation method to study theoretical material on a certain topic, to accompany the lecture, to consolidate the studied material, to organize it. As researcher I. Shevchenko notes, "a multimedia presentation is a set of texts, images, sound, animation and other means of presenting information on a certain topic, which is saved in a file of a special format ..." (Shevchenko, 2012).

5. In the discussion of issues related to the organization of the educational process in primary school it is advisable to use the jury method during the practical classes. It requires the engagement of several "experts" (usually primary school teachers, where students are trained as pedagogical interns), who answer questions from the audience on their practical teaching activities. The experts may also be students who have recently completed a pedagogical practice in the school and want to share their impressions, suggestions, etc.

\section{Research result}

In the process of forming the professional competence of future primary school teachers in our research, we checked the following main components: motivational, informative, operational-active, personal, reflexive (Onyshchenko, 2012). Their characteristics are presented in Table 1.

Table 1 Characteristics of professional competence components (Onyshchenko, 2012)

\begin{tabular}{|c|l|}
\hline $\begin{array}{c}\text { Professional competence } \\
\text { components }\end{array}$ & \multicolumn{1}{|c|}{ Characteristics of professional competence components } \\
\hline Motivational & $\begin{array}{l}\text { Ensuring positive motivation of a student to express and develop } \\
\text { professional and pedagogical competence which is expressed in } \\
\text { interest to pedagogical activity, desire to work as a primary } \\
\text { school teacher, need } \\
\text { for self-education, self-development. }\end{array}$ \\
\hline
\end{tabular}


Opanasenko \& Chernenko, 2020. Formation of the Professional Competence of Future Primary Teachers with the use of Modern Teaching Methods

\begin{tabular}{|c|l|}
\hline \multirow{3}{*}{ Meaningful } & $\begin{array}{l}\text { Students possess scientific professional and pedagogical } \\
\text { knowledge: pedagogical, methodical, special, general } \\
\text { educational, managerial, information technological; ability to } \\
\text { think pedagogically based on the system of knowledge and } \\
\text { experience of cognitive activities. }\end{array}$ \\
\hline Operating-active & $\begin{array}{l}\text { The student's ability to solve practically teaching tasks, } \\
\text { experience, abilities, mastery of pedagogical technologies and } \\
\text { pedagogical management, professional thinking. }\end{array}$ \\
\hline Personal & $\begin{array}{l}\text { Personal and professionally important qualities of personality: } \\
\text { love for children, kindness, altruism, empathy, tolerance, moral } \\
\text { purity, sociability, competitiveness, activity, independence, } \\
\text { initiative, creativity, } \\
\text { flexibility of thinking. }\end{array}$ \\
\hline Reflexive & $\begin{array}{l}\text { The student's ability to effectively and adequately carry out } \\
\text { reflexive processes, to realize reflexive abilities, to provide } \\
\text { processes of self-cognition, self-development and self- } \\
\text { improvement. }\end{array}$ \\
\hline
\end{tabular}

After introducing the above mentioned modern methods of education into the educational process, we checked the level of formation of certain components of professional competence.

Thus, the testing method made it possible to check theoretical knowledge of professional disciplines (meaningful component). The base of test tasks was recorded in the computer, to which only the student had access. The evaluation of the test tasks was carried out independently. The results showed that 20 students $(55,5 \%)$ out of $36(100 \%)$ passed the tests with excellent marks, 12 students $(33,3 \%)$ received good marks, $4(11,1 \%)$ received satisfactory marks.

The solution of situational pedagogical cases (Osadchenko, 2012) made it possible to determine the level of the operating-active and reflexive components of future primary school teachers. Such pedagogical situations were suggested for solution (Matvienko, 2005):

1. The child is careless in learning mathematics, constantly disturbs others, does not listen to the teacher at all, does his own business, but draws very well and loves doing it (What are the pedagogical principles to be guided in this situation? Justify your choice).

2. There is a pupil in the primary school class, he is careless in his daily duties, passive in class life, and he is late for class. (Describe the main ways to implement the principle of individual approach to such students.)

3. Watching the students of the 1st grade, the teacher noticed that one of her students in communication with children is irritable, easily quarrels with friends, often arranges fights. In all her failures, the girl blames anyone but herself. After a fight or quarrel with girls and boys, she comes to the teacher with tears in her eyes and complains about other children. (Determine the aggressiveness of the 
girl. Suggest the right teacher's tactics for communicating with her).

The results of the analysis of the proposed pedagogical situations suggest that $32(88,8 \%)$ students actively participated in the discussion and solving pedagogical problems, expressed their thoughts freely and convincingly and offered various ways of solving situations. Only 4 (11,1\%) students were less active.

Consideration and solution of situational problems, in which the problem situation was simulated, made it possible to trace the students' usage of the complex of knowledge, skills and abilities provided by the meaningful, operatingactive and personal components and necessary for future primary school teachers.

The focus group research method (Lapshyn, 2016) made it possible to discuss with students the problem of introducing new teaching methods and their positive impact on the process of forming professional competence of future teachers.

An example of the questions that were suggested for the focus group survey:

1. Is it worthwhile to significantly change the established approaches to learning disciplines today?

2. Why are innovative methods a necessary condition for successful professional competence development today?

3. Why is the innovative awareness of a student a tool for leadership?

The focus group discussion was dominated by statements of the students about changes in the educational process, introduction of modern teaching methods, innovative methods that stimulate and encourage students to study. The results of the discussion showed the activity of students in expressing their own thoughts, interest in pedagogical profession, creativity, flexibility of thinking. The focus of the discussion was on updating the study of special subjects using modern teaching methods.

In our opinion, it is these components that fully reveal the structure of professional competence of a future primary school teacher and contribute to the clear identification of ways of its development.

\section{Conclusions}

The results of the research obtained in the course of the experiment allow to state that the modern teaching methods effectively influence the formation process of professional competence of future primary school teachers. The students who were involved in the experiment showed positive results. Depending on the manifestation of components in future primary school teachers, it can be claimed that the professional competence required for teaching activities in the New Ukrainian School has been formed. 
Opanasenko \& Chernenko, 2020. Formation of the Professional Competence of Future Primary Teachers with the use of Modern Teaching Methods

After all, it is the professional competence of a teacher that determines the formation of key competencies of students, including (Typical educational programmers, 2018): fluent command of the state language; ability to communicate in the native language; mathematical competence; competence in science, technique and technology; innovation; environmental competence; information and communication competence; life-long learning; civil and social competence; cultural competence; entrepreneurship and financial literacy.

\section{References}

Bibik, N.M. (2004). Competency approach: reflexive application analysis. In Competency Approach in Modern Education: World Experience and Ukrainian Perspectives (pp. 47-52). Kyiv: Nauka.

Encyclopedia of Education. (2004). Kyiv: Yurinkom-Inter.

Khoruzha, L.L. (2003). Ethical Competence of a Future Primary School Teacher: Theory and Practice. Kyiv: The Press of Ukraine.

Korotiaieva, I., \& Kandyba, H. (2019). Using mind-map technology in teaching English to tertiary students majoring in philology. Theoretical and applied problems of modern philology, 2. Retrieved from http://nbuv.gov.ua/UJRN/

Kubitskaya, M.D. (2016). Competent approach in professional teacher training. Educational discourse, 1, 88-95.

Lapshyn, S. (2016). The method of conducting focus groups. Vinnitsa: VSPU.

Matvienko, A.V. (2005). Upbringing of schoolchildren: pedagogical tasks and problems. Kyiv: PC "Foliant".

On approval of the concept of the development of pedagogical education. (2018). Retrieved from https://mon.gov.ua/ua/npa/pro-zatverdzhennya-koncepciyi-rozvitku-pedagogich noyi-osviti

On approval of the professional standard "Primary school teacher in institutions of comprehensive secondary education”. (2018). Retrieved from https://zakon.rada.gov.ua/ rada/show/v1143732-18

Onyshchenko, I. (2012). Model for the formation of professional competence of a future primary school teacher. Teaching and Education of a Gifted Person: Theory and Practice, 8, 94-101.

Osadchenko, I. (2012). Didactic requirements and methods of case formation in the context of training future primary school teachers. Scientific Notes by KSPU, 107, 58-69.

Shevchenko, I. (2012). The use of multimedia presentations as a modern means of education in the system of postgraduate education. A computer in school and family, 1, 23- 26.

Skvortsova, S.A. (2009). Types of professional competence of the teacher. Science and education, 10, 153-156.

Typical educational programmers for general secondary education institutions: 1st - 2nd grades (2018). Kyiv TD “Education-Centre +".

Zubkova, O. (2019). Design-thinking in Education. Retrieved from https://vseosvita.ua/ library/dizajn-mislenna-v-osviti-4703.html 